\title{
Being a nurse leader in bedside nursing in hospital and community care contexts in Norway and Sweden
}

\author{
Elsy Athlin ${ }^{1}$, Reidun Hov $^{2}$, Kerstin Petzäll ${ }^{3}$, Birgitta Hedelin ${ }^{3}$ \\ 1. Department of Health Sciences, Karlstad University, Karlstad, Sweden. 2. Department of Nursing, Hedmark University \\ College, Elverum, Norway. 3. Department of Nursing, Gjøvik University College, Gjøvik, Norway.
}

Correspondence: Elsy Athlin. Address: Department of Health Sciences, Karlstad University, Karlstad, Sweden. Email: elsy.athlin@kau.se

Received: October 2, 2013

DOI : 10.5430/jnep.v4n3p234
Accepted: November 26, 2013 Online Published: January 14, 2014

URL: http://dx.doi.org/10.5430/jnep.v4n3p234

\section{Abstract}

Background: The changes of health care that have been going on the latest decades have affected nurse leaders' role in bedside nursing in hospitals and community care in Norway and Sweden as in many other countries.

Aim: This study aimed at describing nurse leaders' working situation, role experience and role performance in bedside nursing in hospital and community care contexts in Norway and Sweden.

Methods: Twenty-four nurse leaders in three hospitals and ten nursing homes/sheltered accommodations in urban and rural areas in Norway and Sweden participated in qualitative interviews. Data was analyzed using inductive content analysis. In addition background information was used for providing deeper understanding of the leaders' working situation.

Findings: The leader responsibilities concerned safeguarding the quality in daily care, upholding a good workplace environment, developing nursing care, and keeping the budget in balance. Being in an 'in-between' position with more responsibility than authority in the role was common for all leaders. Four characteristic groups of leaders; 'the patient guardian', 'the manager', 'the climber', and 'the unconscious', illustrated different pattern found.

Conclusion: Our study illuminates the necessity of improvement of competence requirements, authority-responsibility balance, administrative and emotional support, and competence development in regard to bedside nurse leaders.

\section{Key words}

Bedside nursing, Community care, Hospital care, Nursing leadership, Nursing quality

\section{Background}

The health care systems in the industrialised world have undergone many reforms intended to improve quality of care, and strengthen cost effectiveness, productivity and efficiency. During the 90s this led to changes in organisations, and decentralisation of decisions, which also affected the nurse leader's role and responsibilities in bedside nursing in hospitals and community care ${ }^{[1-3]}$. New terms were coined which caused vagueness and uncertainty and made it difficult to compare the nurse leader role in different contexts ${ }^{[4,5]}$. In a literature review, Cook ${ }^{[6]}$ found that the difference between nursing 
management, nursing leadership and clinical leadership were scarcely described. In this study the terms 'nurse leader' and 'leader in bedside nursing' will be used irrespective of what term has been used in the studies referred to.

Traditionally, the unique quality of leaders in bedside nursing has been their background as clinical nurses, which has been seen as important for creating an appropriate environment for high quality nursing care ${ }^{[7]}$. However, nursing background as the basis for leadership in bedside nursing has been questioned during the last decade. Voices have claimed that it would be more cost-effective with basic training in management, administration and economy ${ }^{[8]}$. A mediating opinion was stated by Alexander ${ }^{[9]}$, who claimed that the best preparation for a nurse leader for the $21^{\text {st }}$ century would be clinical nursing expertise combined with business administration competence. Nowadays, the nurse leaders on the wards are still expected to ensure that the nursing personnel deliver high quality nursing care ${ }^{[10,11]}$. In addition, especially in hospital organisations, more administrative and human resource tasks have been put on them ${ }^{[8,12]}$. There are also expectations on nurse leaders to take on a central role in development projects and research activities to ensure that the care is evidencebased $^{[13,14]}$. Accordingly, both expectations and responsibilities of nurse leaders in the clinical setting have increased ${ }^{[15]}$.

The great interest for leadership in nursing which has accompanied the changes has resulted in a huge body of literature. Many studies have described the new leader role as comprehensive, complex, and vague ${ }^{[6,16,17]}$ and also as burdensome and stressful ${ }^{[18-20]}$. Others have shown that nurse leaders appreciate their new role, as it provides opportunities for personal development and growth ${ }^{[21,22]}$. Studies have also highlighted nurse leaders' lack of adequate education and competence ${ }^{[8,23]}$ and lack of support in the changing role ${ }^{[18,24]}$.

In Norway and Sweden the organisational changes have meant new positions and tasks for many of the nurse leaders in bedside care ${ }^{[17,25]}$, which concur with what has happened in other countries. Especially in Swedish community care the nursing leadership has been affected, due to the transfer of superior leadership to district managers, without the requirement of these leaders being registered nurses ${ }^{[26]}$. To safeguard the nursing quality in nursing homes and sheltered accommodation, registered nurses are employed to be responsible for the leadership in bedside nursing care ${ }^{[27,28]}$.

\subsection{Rationale for the study}

The literature review provided a comprehensive but rather diverse picture of what it means to be a nurse leader in bedside nursing. Most studies focused on nursing leadership in the context of hospitals, whereas corresponding studies from the community care were scarce. As nurse leaders in hospitals and community care in Norway and Sweden have been the target of many changes during the last decade ${ }^{[29]}$ our study was carried out in order to throw light upon nursing leadership in bedside nursing in two geographic areas where co-operation in the field of competence development has been going on for a number of years ${ }^{[30]}$.

\subsection{Aim}

The aim was to describe nurse leaders' working situation, role experience, and role performance in bedside nursing in hospital and community care contexts in Norway and Sweden.

\section{Methods}

\subsection{Setting}

The study was carried out in three hospitals and ten nursing homes/sheltered accommodations (community care) in urban and rural areas in border districts of Norway and Sweden. The leaders in the hospitals worked in surgery and internal medicine wards, and the community care leaders worked in wards for elderly care. 


\subsection{I nformants}

Permission and names of possible informants were given by the heads of the institutions. The inclusion criteria were to be responsible for the bedside nursing care, and have at least six months of experiences in the leader role from the present workplace. In addition, informants with different age, sex, education, work- and leadership experience were asked for in order to get variation in data. Twenty-four informants fulfilling the inclusion criteria were invited to participate, and twelve nurse leaders from hospitals and twelve from community care agreed, equally divided between the countries. Two of the informants were men.

\subsection{Data collection}

Qualitative interviews were used for data collection about experience and performance of the leader role. A thematic interview guide was created including the themes: reasons for entering nursing leadership, goals and visions, content and responsibility, opportunities and obstacles, and competence development. The guide was tested in one interview per author before data collection. The data collection was carried out between August 2007 and May 2008 at the informants' workplace in an open dialogue. The interviews were made in an open dialogue with probing questions to clarify and deepen the understanding. Twenty-four tape-recorded interviews (six per author) lasting between 45 and 90 minutes were conducted and transcribed verbatim. Before the interviews the informants were asked to fill in a short structured form with demographic and context-related questions, including questions about formal responsibility and authority.

\subsection{Data analysis}

The interviews were analysed with qualitative content analysis ${ }^{[31,32]}$ in collaboration between the authors, who were familiar with both the Norwegian and the Swedish language. The interview texts were read and re-read to make sense of each interview as a whole. Words and phrases which made sense in regard to the topic under study were marked in the text. Meaning units that dealt with the same content were identified and coded, and thereafter condensed, compared, and classified as belonging to a particular group. In this step sub-categories were abstracted and grouped into categories and labelled. Throughout the analysis questions were put to the text such as: What is this? What does it tell about being a leader in bedside nursing? What does it stand for? What else is like this? What does it mean? When searching for similarities and differences in the interviews typical patterns were discerned concerning the informants' view of the leadership role and fundamental values behind it. In a re-analysis of all interviews these patterns were further analysed, condensed and sorted into four categories describing different characteristics of leaders. The researchers collaborated closely in all the steps of analysis in order to strengthen the credibility of the findings. The decisions about which coded material was appropriate to be put into the same category was taken through interpretation ${ }^{[33]}$. When disagreement occurred, the interview and coded material were re-read and discussed again until full agreement was attained in the research group.

The demographic and context-related data from the structured form were manually calculated with percentages, ranges and means.

\subsection{Ethical consideration}

The study was approved by the heads of the institutions involved. Additionally, the study was reported to the Norwegian Social Science Data Services (Nr 19673). The Ethical Code for Nurses and Nursing research ${ }^{[34]}$ was taken into account throughout the study following the issues of voluntariness, confidentiality and integrity of the informants.

\section{Findings}

\subsection{Demographic and context-related data}

The age of the nurse leaders (see Table 1) ranged from 28 to 61 years (mean $=48$ years). All of them, except three who worked in community care, were 40 years old or more. Their legislation as nurses was from 1972 - 2006. Seventeen of 
them had a Diploma degree, and seven had an academic degree (six a Bachelor degree and one a Master degree), of whom five were found in the Swedish contexts. Fifty per cent of the leaders (no difference in the contexts) were specialist nurses, and seven Swedish leaders had academic courses in topics related to medicine or nursing. Such courses were not reported by the Norwegian leaders. Eight leaders reported courses in administration and leadership, of whom four were working in Norwegian community care. Two leaders had no further education after the nursing exam. Most of the leaders had a solid grounding of clinical work experience as nurses (mean variation 16-21 years). The leaders with the lowest work experience worked in community care in both countries (3-5 years of work experience). The experiences of nursing leadership were highest in Swedish hospitals and Norwegian community care. The leaders with the lowest leader experience were also found in these contexts (see Table 1).

The nurse leaders managed wards of different sizes in which the number of beds varied (range 16-40). The highest number was found in Swedish community care and the lowest in Norwegian community care. Also the number and skill mix of nursing personnel varied both between countries and between hospital and community care. The highest rate of registered nurses was found in hospitals in which Norwegian hospitals were mostly staffed (95\%) with registered nurses (RNs), and Swedish hospitals had about $60 \%$ RNs. The community care in both countries had considerably fewer RNs with about 33\% RNs in Norwegian and 10\% RNs in Swedish care institutions.

Table 1. Participant demographics in hospitals and community care from Sweden and Norway

\begin{tabular}{|c|c|c|c|c|}
\hline & \multicolumn{2}{|l|}{ Sweden } & \multicolumn{2}{|l|}{ Norway } \\
\hline & Hospital & Community care & Hospital & Community care \\
\hline $\begin{array}{l}\text { Age (Years) } \\
\text { Mean (range) }\end{array}$ & $52(46-60)$ & $49(36-61)$ & $48(42-51)$ & $44(28-60)$ \\
\hline $\begin{array}{l}\text { RN experiences (Years) } \\
\text { Mean (range) }\end{array}$ & $17^{1}(7-36)$ & $16(3-31)$ & $21(10-29)$ & $16(5-36)$ \\
\hline $\begin{array}{l}\text { Leader experiences in present work place (Years) } \\
\text { Mean (range) }\end{array}$ & $4(1-10)$ & $5(1-9)$ & $4(1-8)$ & $6(<1-12)$ \\
\hline $\begin{array}{l}\text { Total leader experiences (Years) } \\
\text { Mean (range) }\end{array}$ & $13(1-21)$ & $6(3-9)$ & $6(2-14)$ & $9(<1-17)$ \\
\hline
\end{tabular}

Note. ${ }^{1}$ Internal dropout: $\mathrm{n}=1$

\subsection{The formal responsibility and authority of the role}

The findings showed that the leader role in bedside nursing were rather indistinct and vague with regard to formal job-descriptions. Only thirteen leaders reported about written job-descriptions stating their responsibilities and authority. Despite this lack of written documents all informants expressed awareness about the formal responsibility in their role. The nurse leaders at Norwegian and Swedish hospitals and in Norwegian community care reported similar formal responsibility, which concerned nursing quality, nursing administration/staffing, nursing environment and budget. The formal responsibility of Swedish community care leaders differed from this, as it did not include nursing administration/ staffing and budget, and their responsibility for the nursing environment was vague. Despite this they stressed their authority to decide about recruitment of extra personnel in extraordinary situations, and about patients' transfer to hospital.

\subsection{Experience and performance of the leader role in bedside nursing}

The nurse leaders' experience and performance of the leader role were captured in four categories: 1) safeguarding the quality in daily care, 2) upholding a good workplace environment, 3) developing nursing care and 4) keeping the budget in balance. Connections found between the categories will be presented under each heading.

\subsubsection{Safeguarding the quality in daily care}

All nurse leaders stressed their responsibility for safeguarding the quality of care around the clock, including planning, coordinating and controlling the daily care. Some leaders had delegated the daily control and supervision of the nursing personnel to another nurse on the ward, but despite this they stressed their overall responsibility for the nursing quality. 
Being present in the ward was seen as important, as this made it possible to get to know the patients and the personnel, and sense the atmosphere in the ward. By observing the staff's attitudes, behavior, skills and working performance, mistakes could directly be adjusted by means of feedback and supervision.

'I come a little earlier in the morning to talk to the staff before they start their work in order to know what is happening....and I do a little round in the afternoon to see... I am not happy unless everything is ok ......' (Informant nr 12)

To safeguard an adequate number of personnel with relevant competence on every shift was mentioned as one of the most important and demanding tasks by most of the leaders. In the Swedish community care a lot of time was used to delegate nursing tasks to licensed practical nurses and nurse assistants. Especially in community care, but also in hospitals, when competent personnel were lacking some leaders could work 'hands on' in bedside nursing to ensure good quality of the care. This further increased the leaders' workload which was stressed as heavy from before.

The nurse leaders in the hospitals and in the Norwegian community care claimed that new administrative tasks had been imposed on them during recent years, most often without preparation in advance. These new tasks hindered them from being present in the daily care. Many administrative tasks were considered as more appropriate to be carried out by others than nurses.

'There are many more administrative and economic tasks than before ... I think it is about 70 to $80 \%$, but maybe it is more ... '(Informant nr 11)

Administrative support could sometimes be provided from the department of human resources, but this support was described as insufficient.

\subsubsection{Upholding a good workplace environment}

All leaders described their responsibility for the workplace environment and stressed the connection between the personnel's job satisfaction and a high quality of care. Creating a good psychological climate in the ward and involving the personnel in decision-making was seen as an important part of their role. Being a fair, open and encouraging leader, giving honest feed-back and showing respect were expressed as important for upholding the personnel's working morale and job satisfaction. Personnel's negative attitudes that sometimes could be noted were not accepted.

'... I came into a ward with lots of backtalk ... they were talking bad about all and everything. So I had to be determined about that ... every time I heard something I said: I don’t accept this, I don't want such personnel in my ward ...' (Informant nr 21).

The leaders described themselves as mediators in conflicts among the personnel and took an active part in problem-solving. This could sometimes be experienced as positive, but also very challenging, and most leaders expressed their need for support in these issues.

As a good workplace environment was closely related to the workload of the personnel, balancing the workload on each shift was seen as a means to ensure a good workplace environment. A lack of competent personnel could cause stress among the personnel, which in turn impacted negatively both on the workplace environment and nursing quality. Participation in the employment process was seen as important to get the opportunity of controlling the competence of nurses. Leaders who were not involved in this process stressed that this hindered them in upholding quality of care and a good working environment.

\subsubsection{Developing nursing care}

Most of the informants saw themselves as responsible for development and improvement of nursing care. This gave positive challenges and pleasure in work, but was also associated with disappointments and frustrations. Many leaders had visions for their ward, which included competence development of their personnel, and they worked consciously to reach 
their goals. A positive attitude towards development of care and research utilisation was expressed with regard both to themselves and most of the personnel, but lack of time and competence was a hinder.

'We are trying very often to dedicate time for competence development, but sick leave and too many patients in the ward are hindrances, which feels very frustrating ...' (Informant nr 20)

In addition, reorganisations, economic restrains, and changes of rules and routines decided beyond their own control, often hindered ongoing projects. Therefore, authority to make decisions about human recourses and other 'ward affairs' was stressed as a necessity in order to achieve success in development projects. Due to lack of time some leaders had delegated the responsibility for development and improvement of nursing care to another nurse in the ward.

\subsubsection{Keeping the budget in balance}

Most informants, no matter whether they were formally responsible or not, claimed that they operated on a minimum budget, which was not to be exceeded. All of them considered that "budget in balance" was the most outstanding goal their superiors expected them to fulfill, and they struggled hard to reach this. As these economic restrictions hindered them from reaching other goals of high quality of care, good workplace environment and development of care, they experienced the restrictions as a heavy burden.

'You get a little bit weary and fed-up with all the cost-saving measures. It affects every single day...... the constant nagging about the economy. .....' (Informant nr 16).

\subsection{Characteristics of leaders}

Four groups of leaders evolved in the analysis, built on diverse patterns of performance and fundamental values among the informants; the patient guardian, the manager, the climber, and the unconscious. These groups of leaders were unified in the experience of the leader role as an 'in-between' position, which was described as two-sided. The position was seen as rewarding and stimulating with opportunities for influencing changes in the ward, and the emphasis on good collaboration with superiors and loyalty to their decisions was prominent. The other side concerned feelings of being trapped by loyalty towards different levels, groups and interests. These negative experiences were described in terms of heavy burden, loneliness, frustration and guilt. Shared in common was also the experience of a great responsibility which widely exceeded the authority and power to act in accordance with what was regarded the best. Despite the negative experiences, the freedom in the leader role was stressed as a reason for job satisfaction in all groups. With the exception of the climber, the leaders had not chosen the leadership role actively, but had come into it merely by chance, had been asked, induced or persuaded to apply for the position.

\subsubsection{The patient guardian $(n=17)$}

This group, which most nurse leaders from all contexts fitted in included leaders with both a nurse and a leader identity. A distinct professional awareness and knowledge was prominent in thinking and acting. Patient care was a deep concern, and the leaders saw themselves as role models. Having full authority and involvement in decisions in their own field of responsibility was stressed as important.

\subsubsection{The manager $(n=3)$}

This group found in Norwegian community care included leaders who saw administration and budget issues as their main responsibility. They stressed their interest in economic and administrative issues and were satisfied with this content in their job. The necessity of being a nurse for the leader role was questioned, but in the case of a non-nurse in the bedside leader position, a co-leader was seen as necessary in order to cover nursing concerns.

\subsubsection{The climber $(n=2)$}

This group was found in Swedish hospitals and included highly self-aware, self-confident and knowledgeable leaders, who saw career development as a driving force in the leader role. A continuous contact with superiors and being involved in 
decisions about 'the greater whole' in the organisation gave a position of power and authority, which was stressed as important in order to achieve success in the leader role and for their own job satisfaction.

\subsubsection{The unconscious $(n=2)$}

This group was found in the Swedish community care and included leaders who were somewhat unaware of expectations related to the leader role, and with low professional awareness, knowledge and ambition. Patient wellbeing was stressed as an important part of the responsibility but seemed to concern social more than professional issues. The medical focus was predominant, and they saw themselves as a link between the physician and the nursing personnel.

\section{Discussion}

The findings of this study revealed a pattern of similarities, but also differences concerning the responsibilities and opportunities of the nurse leader role in bedside nursing in different care contexts. Many of the leaders lacked written job-descriptions detailing their responsibilities. Despite this most of them stressed nursing quality, nursing administration/ staffing, nursing environment and budget as their responsibilities. They also underlined that these areas were closely intertwined. These areas and their interrelationship are well in agreement both with theory of nursing leadership ${ }^{[35]}$ and previous reports about responsibility of bedside nurse leaders in Western countries ${ }^{[6]}$. However, the situation in the Swedish community care differed because the formal responsibility of the bedside nurse leaders did not include nursing administration/staffing, budget and work environment. Despite this they often had to take on responsibility in these issues in order to safeguard the quality of nursing care. This concurs with what Loo and Thorpe ${ }^{[19]}$ already have pointed out, namely that nurse leaders need to be involved in all key management activities, and specifically in planning and budgeting, in order to take on the responsibility for nursing quality.

A recurrent lack of adequately trained nurses was stressed as a time-consuming issue which hindered the leaders from carrying out other duties. In the Swedish community care the nurse leaders used a great deal of their time delegating nursing tasks to licensed practical nurses or nurse assistants since RNs were lacking. As all delegating of tasks involves a risk of low quality care due to inadequate communication, unclear roles or low competence ${ }^{[37,38]}$, this finding is alarming. Nakata and co-workers ${ }^{[39]}$ have highlighted that the outstanding challenge of today is to find solutions for getting the right number, skills and team-work in the nursing workforce in order ensure quality care, which according to them is a challenge which links nurse leaders globally.

Based on the informants' reports the size of the wards, number of staff and skill-mix varied a lot both between countries, and hospital and community care. The highest rate of RNs was found in hospitals, where the Norwegian hospitals were almost fully staffed with RNs. It was notable that the highest rate of beds was reported in Swedish community care, where also the lowest rate of RNs was found. These findings are interesting in the light of the many reports where staffing, skill-mix and quality of care are stressed as interdependent variables, with a high rate of RNs as an important quality indicator $^{[40,41]}$.

The administrative every-day tasks that were put on the nurse leaders were often experienced as too heavy, since adequate support from the department of human resources was lacking. Loo and Thorpe ${ }^{[19]}$ reported similar problems, and argued that if bedside nurse leaders are given the overall responsibility for nursing quality a sufficient support system is imperative. Leaders in our study stressed that many of their administrative tasks could be performed by others than nurses, and some even expressed that the bedside leader role could be held by a non-nurse. Simultaneously, our findings illustrated what is already well-known, namely that bedside leadership holds many dimensions which are significant for high quality of nursing care ${ }^{[11,42]}$.

A striking finding was all leaders' experience of being in an "in-between” position. Most of them appreciated their role because of the opportunities to develop quality of care for the patients, and workplace environment and job-satisfaction for 
the personnel. Some of them also underlined power, authority and responsibility as a positive force in the role. This is well in line with other studies pointing out factors of importance for job-satisfaction among nurse leaders ${ }^{[2,43,44]}$. However, the 'in between-position' also meant conflicting expectations, which are in line with the findings of Skytt and co-workers ${ }^{[45]}$, showing the conflict between superiors' expectations on nurse leaders and their own professional goals. It was notable in our study that the leaders' authority and power was considered as less than their responsibility, an issue which often hindered them from reaching their goals. Despite this they were strictly loyal to decisions taken by their superiors. It was also notable that 'budget in balance' was experienced as the main requirement from the superiors, which seemed to overshadow all the other goals. Putting all this together it is easy to understand the feelings of frustration and guilt the nurse leaders expressed. This highlights what already has been stressed, namely that clinical supervision would be valuable for nurse leaders when they step into the leader role ${ }^{[36]}$.

Our findings illuminated a question previously raised by Drach-Zahavy and Dagan ${ }^{[46]}$, if economy has become the main goal in the health-care system. We are talking about high quality of care whilst economic balance is the paramount goal. If so, this would be a great pitfall for the welfare of society, as it may harm the patients' health and well-being and cause frustration and burn-out among nurse leaders and their personnel ${ }^{[20]}$. The characteristic groups of leaders suggested in our study may illustrate these different goals, which are grounded in values of humanism and economism ${ }^{[46]}$. The patient-guardian, who was identified among most of the leaders, described leaders who were building their role on professional nursing values such as caring, dignity and respect, but were caught in the demands of economic goals. The managers, saw nursing leadership only as administrative and management activities. These leaders' goals may be understood as driven by the goal of cost-effectiveness. The climber fitted in both value systems, with both quality of care and 'budget in balance' as their goals. However, these leaders also saw power and authority as values in themselves as it could be used for their own career development. Finally we have the unconscious, described as unaware, humanistic-thinking leaders with a wish to do good for the patient, but being short of professional knowledge and ambitions. The question is: what kind of leaders should be the best in the bedside nursing of tomorrow? Stanley ${ }^{[47,48]}$ has argued that nurse leadership development nowadays is based on theories and models best suited to business and management functions instead of nursing. He claimed that if we want to develop effective nurse leaders in clinical nursing this must be done without losing the core values and principles that guide nursing. According to him this can be done by following the theory of congruent leadership which is built on congruence between the leaders' actions and activities and their values and beliefs.

Most leaders in our study had got into the leadership role merely by chance without any preparation beforehand, which is remarkable when taking their comprehensive and expanded role into consideration. Only one third of them had academic qualifications, and most of them lacked training in management and economics. Despite this they were expected to be responsible for these issues. Cook and Leathard ${ }^{[23]}$ found that much leadership training was undertaken after designation to the leader role. They claimed that people should be prepared in advance for the leader role. This lack of relevant and higher education, which has been reported for many years ${ }^{[1]}$, is incompatible with qualifications of a nurse leader of today, who has a comprehensive responsibility for the quality of nursing care. As the leader in clinical nursing has a great impact not only on the outcome of care but also on the working life for the staff ${ }^{[49]}$, the requirements of proper education should be clearly addressed before engagement in the role.

As in many other studies ${ }^{[25,50]}$ most of our leaders had positive attitudes to competence development, quality improvement and research utilisation. However, lack of time and budget restrictions often hindered them from carrying out these activities. Johansson and co-authors ${ }^{[50]}$ suggested on the basis of their findings that the more experienced and welleducated nurse leaders are, the more positive attitudes and opportunities they declare with regard to research activities. This provides arguments for higher-educated nurse leaders in bedside nursing, which has also been stressed by others ${ }^{[36,51]}$. 


\section{Methodological considerations}

As this was a qualitative study, different measures were taken to ensure trustworthiness. Somewhat few informants took part from each context. Therefore the findings must be interpreted with some caution. However, in qualitative studies data is considered rather than the subjects ${ }^{[52]}$, and in our study the data was judged as rich and adequate to the research question. To get variation in data, informants with different age, sex, education, work- and leadership experience were chosen. Background information about informants and contexts were used for providing deeper understanding of the leaders' working situation. Only two men were included, but their experiences were similar to others and as the findings corresponded with previous studies, the inequality in gender may not have influenced the findings. Using four researchers for data collection could have threatened the study's credibility because of differences in language and interview style. As the researchers were well acquainted with the two languages, and pilot interviews were carefully conducted, this risk was judged to be low. Throughout the analysis process the researches worked together, reviewing each other's transcripts and the emerging categories in order to safeguard credibility. To enhance transferability, the informants and the contexts are described as exactly as possible, which may facilitate application of findings in other care contexts ${ }^{[53]}$.

\section{Conclusion and clinical relevance}

Our study highlighted many already well-known obstacles leaders in bedside nursing are facing, of which the lack of congruence between responsibility and authority should be emphasized, as this obstructs the goals of high quality of care and working environment. The findings stress the importance of improvement of competence requirements, authorityresponsibility balance, administrative and emotional support, and competence development in regard to bedside nurse leaders. The implications of our findings should concern nurse leaders and managers on different levels in hospitals and community care who are involved in safeguarding high quality care and a healthy working environment. To understand more about positive and negative factors in the bedside nurse leader role in different care contexts more research is needed.

\section{References}

[1] Foster D. The development of nurses as managers: the prevalence of the self-development route. Journal of Nursing Management. 2000; 8: 193-199. http://dx.doi.org/10.1046/j.1365-2834.2000.00169.x

[2] Jooste K. Leadership: a new perspective. Journal of Nursing Management. 2004; 12: 217- 223. PMid:15089960 http://dx.doi.org/10.1111/j.1365-2834.2003.00450.x

[3] Bradshaw A. Is the ward sister role still relevant to the quality of patient care? A critical examination of the ward sister role past and present. Journal of Clinical Nursing. 2010; 19: 3555-3563. PMid:20964746 http://dx.doi.org/10.1111/j.1365-2702.2010.03374.x

[4] Williams A, McGee P \& Bates L. An examination of senior nursing roles: challenges for the NHS. Journal of Clinical Nursing. 2001; 10: 195-203. http://dx.doi.org/10.1111/j.1365-2702.2001.00472.x

[5] Cook MJ. The renaissance of clinical leadership. International Nursing Review. 2001; 48: 38-46. http://dx.doi.org/10.1046/j.1466-7657.2001.00040.x

[6] Surakka T. The nurse manager's work in the hospital environment during 1990 and 2000s: responsibility, accountability and expertise in nursing leadership. Journal of Nursing Management. 2008; 16: 525-534. PMid:18558923 http://dx.doi.org/10.1111/j.1365-2834.2008.00901.x

[7] Oroviogoicoechea C. The clinical nurse manager: a literature review. Journal of Advanced Nursing. 1996; $24: 1273-1280$. http://dx.doi.org/10.1111/j.1365-2648.1996.tb01035.x

[8] Duffield C \& Franks H. The role and preparation of first-line nurse managers in Australia: where are we going and how do we get there? Journal of Nursing Management. 2001; 9: 87-91. PMid:11879450 http://dx.doi.org/10.1046/j.1365-2834.2001.00214.x

[9] Alexander C. The nurse executive in the 21st century: how do we prepare? Nursing Administration Quarterly. $1997 ; 22: 76-82$. http://dx.doi.org/10.1097/00006216-199702210-00013

[10] Nilsson K. Mandate-Power-Management. A study of how First-Line Nurse Managers' Leadership is constructed. Swedish Dissertation, Acta Universitatis Gothoburgensis, Göteborg, Sweden, 2003.

[11] Wong CA \& Cummings GG. The relationship between nursing leadership and patient outcomes: a systematic review. Journal of Nursing Management. 2007; 15: 508-521. PMid:17576249 http://dx.doi.org/10.1111/j.1365-2834.2007.00723.x 
[12] Townsend K, Wilkinson A, Bamber G \& Allan C. Accidental, unprepared, and unsupported: clinical nurses becoming managers. The International Journal of Human Resource Management. 2012; 1: 204-220. http://dx.doi.org/10.1080/09585192.2011.610963

[13] Marriner Tomey A. Nursing leadership and management effects work environments. Journal of Nursing Management. 2009; 17: 15-25. PMid:19166518 http://dx.doi.org/10.1111/j.1365-2834.2008.00963.x

[14] Kitson A, Silverston H, Wiechula R, Zeitz K, Marcoionni D \& Page T. Clinical nursing leaders’, team members’ and service managers' experiences of implementing evidence at a local level. Journal of Nursing Management. 2011; 19 : 542-555. PMid:21569151 http://dx.doi.org/10.1111/j.1365-2834.2011.01258.x

[15] Tørstad S \& Bjørk ID. Nurse leaders’ views on clinical ladders as a strategy in professional development. Journal of Nursing Management. 2007; 15: 817-824. PMid:17944607 http://dx.doi.org/10.1111/j.1365-2934.2007.00769.x

[16] Gould D, Kelly D, Goldstone L \& Maidwell A. The changing training needs of clinical nurse managers: exploring issues for continuing professional development. Journal of Advanced Nursing. 2001; 1: 7-17. http://dx.doi.org/10.1046/j.1365-2648.2001.3411735.x

[17] Johansson G, Pörn I, Theorell T \& Gustavsson B. A first-line nurse manager’s goal-profile. Journal of Clinical Nursing. 2006; 16: 149-159. PMid:17181677 http://dx.doi.org/10.1111/j.1365-2702.2006.01446.x

[18] Koivula M \& Paunonen-Ilmonen M. Ward sisters' objectives in developing nursing and problems with development. Journal of Nursing Management. 2001; 9: 287-294. http://dx.doi.org/10.1046/j.1365-2834.2001.00252.x

[19] Loo R \& Thorpe K. Making female first-line nurse managers more effective: a Delphi study of occupational stress. Women in Management Review. 2004; 2; 88-97. http://dx.doi.org/10.1108/09649420410525298

[20] Shirey MR. Stress and Coping in Nurse managers: Two decades of research. Nursing Economics; 2006; 4: $193-211$.

[21] Bondas T. Paths to nursing leadership. Journal of Nursing Management. 2006; 14; 332-339. PMid:16787467 http://dx.doi.org/10.1111/j.1365-2934.2006.00620.x

[22] Lee H \& Cummings GG. Factors influencing job satisfaction of front-line nurse managers: a systematic review. Journal of Nursing Management. 2008; 16: 768-783. PMid:19017239 http://dx.doi.org/10.1111/j.1365-2834.2008.00879.x

[23] Cook MJ \& Leathard HL. Learning for clinical leadership. Journal of Nursing Management. 2004; 12: 436-444. PMid:15509273 http://dx.doi.org/10.1111/j.1365-2834.2004.00420.x

[24] Courtney MD, Yacopetti JK, James C, Wash AM \& Finnlayson KJ. Comparison of roles and professional development needs of nurse executives working in metropolitan, provincial, rural or remote settings in Queensland. The Australian Journal of Rural Health. 2002; 4; 2002-2008.

[25] Ødegård Kjøs B, Botten B, Roth Gjevjon E \& Romøren TI. Quality work in long-term care: the role of first-line leaders. International Journal for Quality in Health Care. 2010; 5: 351-357. PMid:20615926 http://dx.doi.org/10.1093/intqhc/mzq035

[26] Karlsson I. Förväntningar och realitet för sjuksköterskor verksamma på äldreboenden (Expectations and Reality for Registered Nurses Active in Homes for the Elderly). Dissertation. Karolinska Institutet, Stockholm, 2007.

[27] Larsson Kihlgren A, Fagerberg L, Skovdahl K \& Kihlgren M. Referrals from home care to emergency hospital care: basis for decisions. Journal of Clinical Nursing. 2003; 12: 28-36. http://dx.doi.org/10.1046/j.1365-2702.2003.00682.x

[28] National Board of Health and Welfare. Kompetensbeskrivningar för legitimerad sjuksköterska (Description of Competence for Registered Nurses), National Board of Health and Welfare, Stockholm, 2003.

[29] Råholm M-B, Hedegaard BL, Löfmark A \& Slettebø Å. Nursing education in Denmark, Finland, Norway and Sweden - from Bachelor's Degree to PhD. Journal of Advanced Nursing. 2010; 9: 2126-2137.

[30] The University Alliance of Inner Scandinavia. 2007. On-line: www.change-on-borders.net/timeline/forum2.php

[31] Burnard P. Teaching the analysis of textual data: an experiential approach. Nursing Education Today. 1996; 4: $278-281$. http://dx.doi.org/10.1016/S0260-6917(96)80115-8

[32] Elo S \& Kyngäs H. The qualitative content analysis process. Journal of Advanced Nursing. 2008; 1: 107-115. PMid:18352969 http://dx.doi.org/10.1111/j.1365-2648.2007.04569.x

[33] Dey I. Qualitative data analysis. A user-friendly guide for social scientists. Routledge, London: 1993. http://dx.doi.org/10.4324/9780203412497

[34] Northern Nurses' Federation. Ethical guidelines for nursing research in the Nordic Countries. Nordic Journal of Nursing Research (Vård i Norden); 2003; 23; 1-5.

[35] Huber D. Leadership and nursing care management. 4th Edition. W.B. Saunders Company. Philadelphia, 2009.

[36] Mc Callin AM \& Frankson C. The role of the charge nurse manager: a descriptive explorative study. Journal of Nursing Management. 2010; 18: 319-325. PMid:20546472 http://dx.doi.org/10.1111/j.1365-2834.2010.01067.x

[37] Potter P, Deshields T \& Kuhrik M. Delegation practices between registered nurses and nursing assertive personnel. Journal of Nursing Management. 2010; 18: 157-165. PMid:20465743 http://dx.doi.org/10.1111/j.1365-2834.2010.01062.x 
[38] Bystedt M, Eriksson M \& Wilde-Larsson B. Delegation within municipal health care. Journal of Nursing Management. 2011; 8: 534-541. PMid:21569150 http://dx.doi.org/10.1111/j.1365-2834.2010.01202.x

[39] Nakata Y, Yasukawa F \& Buchan J. Nursing workforce: global challenges and solutions. Journal of Clinical Nursing. 2008; 17: 3261. PMid:19146583 http://dx.doi.org/10.1111/j.1365-2702.2008.02635.x

[40] Aiken LH, Clarke SP \& Sloane DM. Hospital staffing, organization, and quality of care: Cross-national findings. Nursing Outlook. 2002; 5: 187-190. http://dx.doi.org/10.1067/mno.2002.126696

[41] Haycock-Stuart E \& Kean S. Does nursing leadership affect the quality of care in the community setting? Journal of Nursing Management. 2012; 20: 372-381. PMid:22519615 http://dx.doi.org/10.1111/j.1365-2834.2011.01309.x

[42] Davidson PM, Elliot D \& Daly J. Clinical leadership in contemporary clinical practice: implications for nursing in Australia. Journal of Nursing Management. 2006; 14: 180-187. PMid:16600005 http://dx.doi.org/10.1111/j.1365-2934.2006.00555.x

[43] Chiok Foong Loke J. Leadership behaviors: effects on job satisfaction, productivity and organizational commitment. Journal of Nursing Management. 2001; 9: 191-204. http://dx.doi.org/10.1046/j.1365-2834.2001.00231.x

[44] Nilsson K \& Furåker C. Learning leadership through practice - health care managers' experience. Leadership in Health Services. 2012; 25: 106-122. http://dx.doi.org/10.1108/17511871211221037

[45] Skytt B, Ljunggren B, Sjödén P-O \& Carlsson M. The roles of the first-line nurse manager: perceptions from four perspectives. Journal of Nursing Management. 2008; 16: 1012-1020. PMid:19094115

[46] Drach-Zahavy A \& Dagan E. From caring to managing and beyond: an examination of the head nurse's role. Journal of Advanced Nursing. 2002; 1; 19-28. http://dx.doi.org/10.1046/j.1365-2648.2002.02142.x

[47] Stanley D. Role conflict: leaders and managers. Nursing Management. 2006; 5; 31-37.

[48] Stanley D. Congruent leadership: values in action. Commentary. Journal of Nursing Management. 2008; 16; 519-524. PMid:18558922 http://dx.doi.org/10.1111/j.1365-2834.2008.00895.x

[49] Failla KR \& Stichler JF. Managers and staff perceptions of the manager's leadership style. Journal of Nursing Administration. 2008; 11; 480-487. PMid:18997553 http://dx.doi.org/10.1097/01.NNA.0000339472.19725.31

[50] Johansson B, Fogelberg-Dahm M \& Wadensten B. Evidence-based practice: the importance of education and leadership. Journal of Nursing Management. 2010; 18: 70-77. PMid:20465731 http://dx.doi.org/10.1111/j.1365-2834.2009.01060.x

[51] Burke LE, Schlenk EA, Sereika SM, Cohen SM, Happ MB \& Dorman JS. Devloping research competence to support evidence-based practice. Journal of Professional Nursing. 2005; 6: 358-363. PMid:16311231 http://dx.doi.org/10.1016/j.profnurs.2005.10.011

[52] Sandelowski, M. The problem of rigor in qualitative research. Advances in Nursing Science. 1986; 4: 27-37. PMid:3083765 http://dx.doi.org/10.1097/00012272-198604000-00005

[53] Polit DF \& Beck CT. Essentials of Nursing Research: Appraising Evidence for Nursing Practice. Lippincott Williams \& Wilkins, Philadelphia: 2009. 